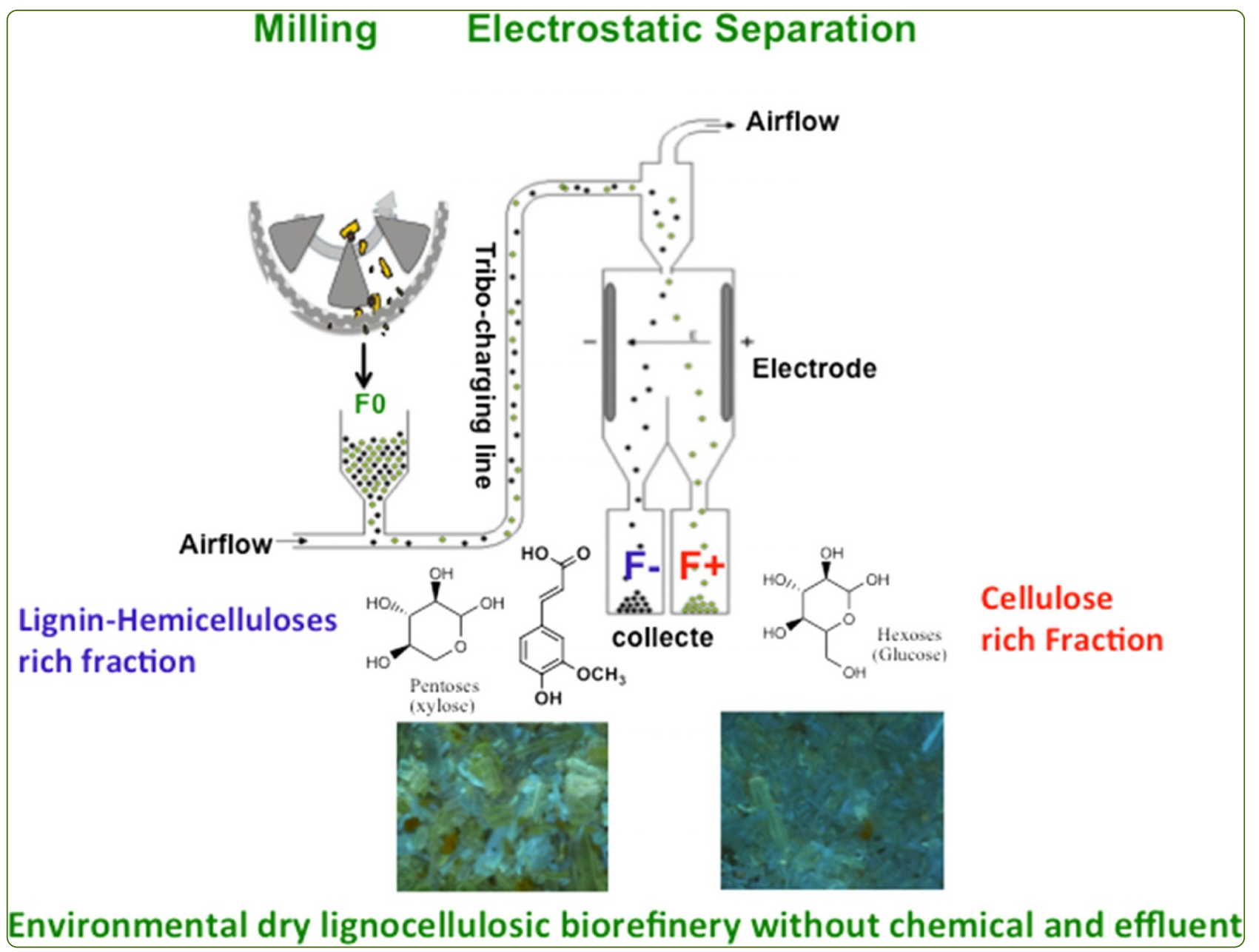

\title{
New dry technology of environmentally friendly biomass refinery: glucose yield and energy efficiency
}

Barakat and Rouau 


\title{
New dry technology of environmentally friendly biomass refinery: glucose yield and energy efficiency
}

\author{
Abdellatif Barakat ${ }^{*}$ and Xavier Rouau
}

\begin{abstract}
Background: Today, most of pretreatments used to convert biomass into biofuels are based on expensive chemical processes that not only do not keep the major components intact after separation, but also consume water and generate many effluents. However, dry fractionation technologies are an important step for future biomass biorefineries since they do not require chemicals and do not generate wastewater. Therefore, the aim of the present study was to evaluate the feasibility of using milling combined with an electrostatic fractionation (ES) of wheat straw (WS) as a way to separate fractions that are enriched in cellulose and more enzymatically accessible, from recalcitrant tissues enriched in lignin-hemicelluloses, in order to produce biofuels.
\end{abstract}

Results: After milling, WS particles are introduced into a tribo-electrostatic separator, where they are positively or negatively charged by tribo-electricity. Then they are introduced into a separation cell comprising two electrodes ( + and - ). The negative electrode attracts the positively charged particles and the positive electrode attracts the negatively charged particles. Results show that amorphous cellulose rich particles were clearly more abundant in positively charged fractions $(F+)$, and loose crystalline cellulose, lignin-xylan and ash-containing material were more abundant in negatively charged fractions $(F-)$. Indeed, positively charged fractions $(F+)$ are more accessible upon enzymatic hydrolysis, which resulted, for example, in sugars yield of $43.5 \%$ glucose $\left(254 \mathrm{~g} \mathrm{Kg}^{-1}\right)$ for F2B + compared to $25.2 \%\left(103 \mathrm{~g} \mathrm{Kg}^{-1)}\right.$ for F2A-, and $26.3 \%\left(130 \mathrm{~g} \mathrm{Kg}^{-1}\right)$ for unfractionated WS F0, respectively.

Conclusions: The combination strategy of milling and ES fractionation could improve the economic feasibility by low energy consumption $\left(10.5 \mathrm{WhKg}^{-1}\right)$ and it produces reactive lignocelluloses particles with different physicochemical structures, which can be converted easily into biofuels and biomaterials without generating toxic effluents.

Keywords: Wheat straw, Biorefinery, Milling and electrostatic fractionation, Biofuels

\section{Background}

Lignocellulosic plant cell walls consist mainly of cellulose, hemicelluloses and lignin. These polymers together with small amount of other components, like acetyl groups, minerals, proteins and phenolic substituents, are organized in complex three-dimensional structures, which are not uniform for different plants. Moreover, lignocellulosic plants consist of different botanical parts of various tissues present in different proportions, each tissue having its own physical properties and biochemical compositions [1-3]. In a biomass biorefinery situation, the separation of

\footnotetext{
* Correspondence: barakat@supagro.inra.fr

INRA, UMR 1208 Ingénierie des Agropolymères et Technologies Emergentes 2, Place Pierre Viala, 34060 Montpellier, cedex 1, France
}

lignocellulose into its major tissues and components constitutes the first step of its refining to high-value-added products $[4,5]$. Today, most of lignocellulosic fractionation technologies or pretreatments are based on expensive chemical processes (pulping, acidic hydrolysis, solvent extraction, alkaline and acid extraction, steam and ammonia explosion and so on) which do not keep the major components intact after separation and generate high toxic effluents [6]. Achieving high fractionation yields and maintaining the integrity of the macromolecular fractionation products without using a high quantity of chemicals and without generating wastewater are of major importance, regarding the effectiveness of the refining process. 
Mechanical or dry fractionation could deconstruct the lignocellulosic biomass at different levels of the plant [7-9]. The development of a dry separating operation combined milling step can therefore allow the separation of parts of plants, tissues and cells and the acquisition of different enriched fractions with different physical and physicochemical properties. A dry fractionation or refinery of lignocellulosic biomass without using chemical and water could allow to produce different tissues enriched in cellulose, hemicelluloses and/or lignin and increase the efficiency of processes while reducing the associated costs and effluent production $[7,10]$. These processes are based on a combination of fragmentation and separation steps, which are carried out by a mechanical pretreatment followed by several types of fractionation technologies [11-13].

Papatheofanous et al. [12] developed a dry fractionation of yellow winter wheat straw (WS), which was initially milled by a disc mill and separated into two fractions by sieving on a $1 \mathrm{~mm}$ screen - chips containing mostly internodes and meal consisting mainly of ground leaves and nodes [12]. The authors showed that all internodes passed in the chip fraction and that the internode fraction $(63 \%$ of the whole straw) contained $8 \%$ more cellulose, $9 \%$ more lignin and $10 \%$ less ash than the unfractionated material [12]. Chundawat et al. [14] also showed that corn stover fractions with a high corn leaf content were found to be more susceptible to enzymatic hydrolysis [14]. Zhu et al. [15] reported that the very fine sample $(<0.127 \mathrm{~mm})$ has a completely different chemical composition as compared to those of the rest of samples. The fine fraction contains about $40 \%$ more lignin and 33\% less cellulose than the rest of the fractions. Furthermore, this sample has a much larger surface area and is more susceptible to enzymatic hydrolysis. Fractionation of fibrous fraction from steam-exploded rice straw (SERS) with a high moisture content has been studied with respect to the separation degree of fibrous tissue versus non-fibrous tissue including epidermal, parenchyma and vessel tissue using a fluidized bed opposed jet mill [9]. Chemical composition and fiber characteristics, such as fiber size and composed cell proportion, were studied for the separated fibrous fraction of SERS. A high amount of cellulose fibrous fraction (70.4\%), with $63.1 \%$ fiber cell content and $65.6 \%$ cellulose content, was produced from the fractionation process. The fiber characteristics of this fractionated fibrous fraction were: mean length $(0.97 \mathrm{~mm})$, mean width $(8.6 \mu \mathrm{m})$, fiber cell $(63.1 \%)$, parenchyma cell $(33.5 \%)$, epidermis cell $(2.4 \%)$ and vessel cell (1\%). The fluidized bed opposed jet mill method is suitable for producing high-fiber tissue content fractions without extensively damaging the raw fibers [9].

The combination of low-severity steam explosion and superfine grinding has been studied with respect to side products generation and enzymatic hydrolysis efficiency
$[9,16]$. The superfine ground product hydrolyzed at the highest rate produced the most elevated levels of reducing sugars $(61.4 \%)$ after 24 hours of hydrolysis. This is 2.8 and 2.3 times higher than those from coarsely pulverized and steam-exploded rice straw, respectively. Hemery et al. [11,17] fractionated wheat bran by combination of ultrafine dry milling and electrostatic separation. The objective was to break down bran tissues in order to separately isolate their sub-cellular constituents (cell walls rich in fiber versus cell content rich in micronutrients). In this case, particles are conveyed by compressed air in a charging line where they are charged by tribo-electricity (Figure 1a and b). This type of separation was notably used successfully to prepare fractions concentrated in aleurone and pericarp from wheat bran $[11,17]$. The authors showed that fiber-rich particles of pericarp were more abundant in the fractions of negatively charged particles, and aleurone cell walls ( $\beta$-glucans, arabinoxylans and ferulic acid) and loose protein containing material from aleurone and endosperm was more abundant in the positively charged particles.

The aim of the present study was to evaluate the potential of using ultrafine grinding followed by electrostatic fractionation as a way to obtain or separate different tissues enriched in cellulose and/or lignin-hemicelluloses from WS for biofuels and biomaterials production. This biorefining approach suggested the combination of two dry mechanical technologies (Figure 1): 1) Ultrafine milling with the aim of fragmenting and dissociating different lignocellulosic tissues and components (Figure 1a and b); 2) Electrostatic separation (ES) based on the preloading of particles with a subsequent separation in an electrical field (Figure $1 \mathrm{a}$ and $\mathrm{b}$ ).

The influence of the fractionation steps on the biochemical composition, particle size and microstructure were studied, and the interest of the different fractions was evaluated.

\section{Results and discussion}

Structural properties and biochemical composition of wheat straw fractions prepared by electrostatic separation technology

On an industrial scale, electrostatic separation (ES) is used as a technology for electric or polymers waste separation. For instance, ES can separate efficiently different polymers with various physicochemical properties (polyvinyl chloride, polyethylene and so on) or metals from polymers $[18,19]$. In our laboratory we developed this technology with the objective to perform a dry fractionation lignocellulose biorefinery without effluent generation. Dry fractionation of WS, developed in this study, is a combination of two different technologies (Figure 1a and b). One is a structural deconstruction and dissociation of the plant cell wall tissues and macromolecules 


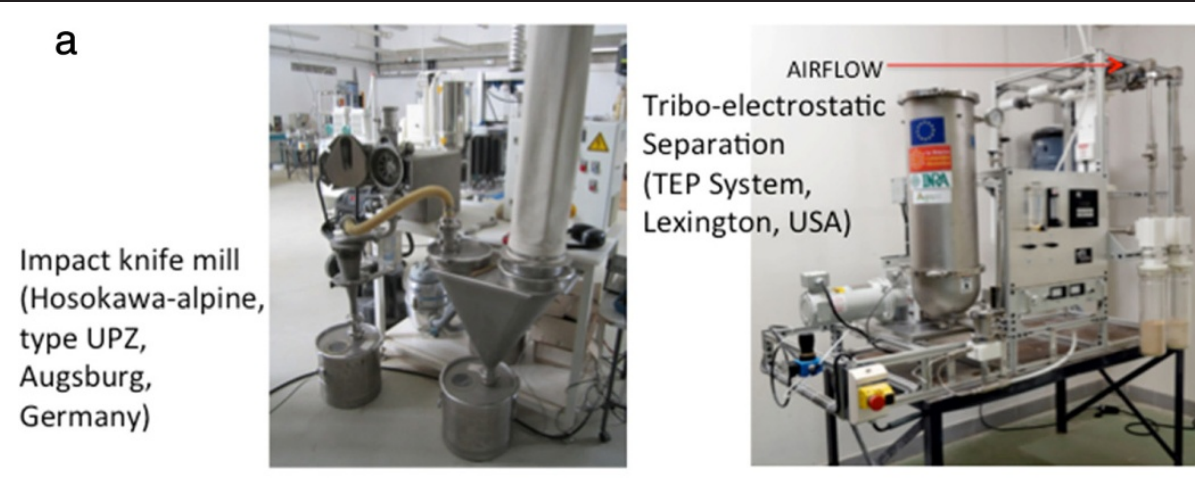

\section{b}

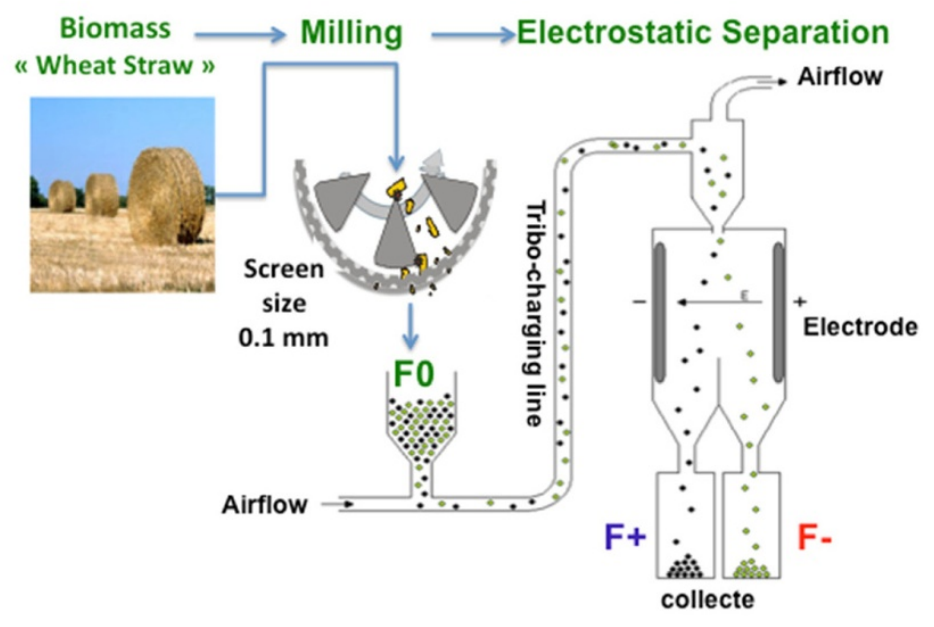

C

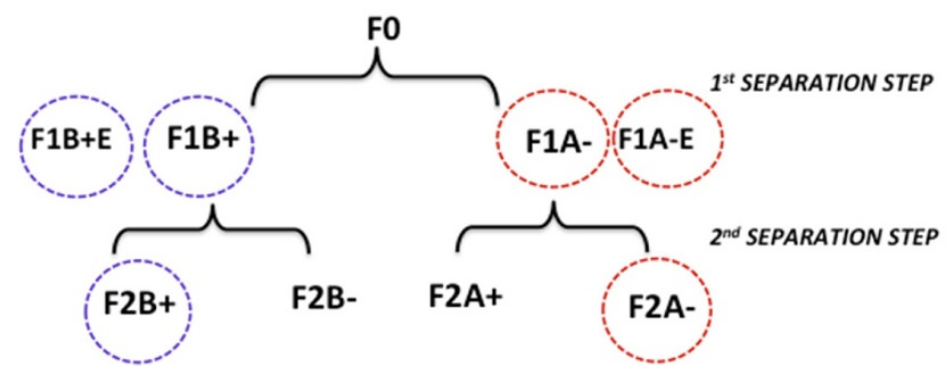

Figure 1 Innovative dry fractionation biorefinery scheme developed in this study using the combination of milling and electrostatic separation: a) Photo of impact mill pilot (type UPZ, Hosokawa-alpine, Augsburg, Germany) and Tribo-electrostatic Separator Pilot (TEP Systems, Lexington, United States) used in this study; b) Dry fractionation route and principal of electrostatic separation; c) Fractionation scheme and preparation of electrostatic fractions.

by ultrafine milling (knife milling with a screen size of $0.1 \mathrm{~mm}$ ). The other one is an electrostatic separation (ES) or fractionation in order to isolate and separate different tissues or fractions, according to their biochemical composition and surface properties. For this purpose, two successive steps of electrostatic fractionation were carried out, using WS powder (with $0.1 \mathrm{~mm}$ screen size), as the starting material F0 (Figure 1b and c). Samples were collected after each separation step, yielding eight fractions (Figure 1c). The particles adhering to the electrodes were also collected but only at the first step named F1A-E and F1B+E fractions. F0, F1A-, F2A-, F2B-,
$\mathrm{F} 1 \mathrm{~A}-\mathrm{E}, \mathrm{F} 1 \mathrm{~B}+, \mathrm{F} 2 \mathrm{~B}+, \mathrm{F} 2 \mathrm{~A}+$ and $\mathrm{F} 1 \mathrm{~B}+\mathrm{E}$ samples were analyzed for their particle size; color, biochemical composition, crystallinity and microstructure and enzymatic accessibility. The yield of different fractions is given in Table 1. The general characteristics and physicochemical properties of lignocellulosic materials studied are also summarized in Table 1.

Results show that the biochemical and physicochemical properties of the different fractions produced varied according to the charge of particles in the fractions and the number of separation steps carried out. The fluorescence microscopy analyses showed that the positively 
Table 1 Biochemical composition and physicochemical properties of different WS fractions

\begin{tabular}{|c|c|c|c|c|c|c|c|c|c|}
\hline \multirow[t]{2}{*}{ Fractions } & \multirow[t]{2}{*}{ Recovery (\%) } & \multirow[t]{2}{*}{$D_{50}(\mu \mathrm{m})^{b}$} & \multicolumn{4}{|l|}{$(\% \mathrm{w} / \mathrm{w})^{\mathrm{b}}$} & \multirow{2}{*}{$\begin{array}{l}\text { Hem: } \\
\text { Cell }\end{array}$} & \multirow[t]{2}{*}{$\mathrm{Crl}(\%)^{\mathrm{a}}$} & \multirow[t]{2}{*}{$\mathrm{SA}\left(\mathrm{m}^{2} / \mathrm{g}\right)$} \\
\hline & & & Ash & Lignin & Hem & Cell & & & \\
\hline Fo & - & $81.9 \pm 3.4$ & $4.5 \pm 1.1$ & $21.5 \pm 1.3$ & $29.1+1.2$ & $45.4 \pm 2.4$ & 0.66 & $54.9 \pm 0.8$ & 43.6 \\
\hline F1A- & $35 \pm 4.2$ & $81.2 \pm 2.2$ & $5.1 \pm 0.8$ & $22.4 \pm 1.7$ & $31.6 \pm 1.7$ & $40.9 \pm 2.0$ & 0.77 & $58.8 \pm 0.0$ & 42.5 \\
\hline F1A-E & $4 \pm 1.2$ & $42.2 \pm 1.2$ & $15.3 \pm 2.2$ & $16.7 \pm 2.2$ & $30.3 \pm 0.8$ & $37.6 \pm 0.9$ & 0.81 & $63.5 \pm 2.2$ & 70.7 \\
\hline F2A- & $22 \pm 2.6$ & $95.7 \pm 2.7$ & $5.2 \pm 1.3$ & $21.3 \pm 0.9$ & $32.6 \pm 1.5$ & $40.8 \pm 1.4$ & 0.82 & $60.4 \pm 1.7$ & 37.3 \\
\hline F2B- & $28 \pm 4.5$ & $75.8 \pm 1.8$ & $4.8 \pm 0.9$ & $20.9 \pm 2.2$ & $29.1 \pm 0.8$ & $45.2 \pm 1.1$ & 0.63 & $60.1 \pm 0.0$ & 47.1 \\
\hline $\mathrm{F} 1 \mathrm{~B}+$ & $58 \pm 4.6$ & $52.2 \pm 3.1$ & $3.7 \pm 0.8$ & $18.3 \pm 1.1$ & $22.8 \pm 1.7$ & $55.2 \pm 1.6$ & 0.45 & $51.9 \pm 1.1$ & 60.2 \\
\hline $\mathrm{F} 1 \mathrm{~B}+\mathrm{E}$ & $5 \pm 1.3$ & $44.9 \pm 0.7$ & $2.9 \pm 0.4$ & $16.3 \pm 1.3$ & $21.8 \pm 1.1$ & $58.9 \pm 1.2$ & 0.37 & $51.3 \pm 2.1$ & 76.4 \\
\hline $\mathrm{F} 2 \mathrm{~B}+$ & $32 \pm 5.2$ & $62.9 \pm 1.2$ & $2.6 \pm 0.4$ & $17.7 \pm 0.8$ & $21.7 \pm 0.8$ & $58.4 \pm 0.8$ & 0.37 & $52.3 \pm 0.7$ & 63.2 \\
\hline $\mathrm{F} 2 \mathrm{~A}+$ & $16 \pm 2.6$ & $55.5 \pm 1.5$ & $3.5 \pm 1.0$ & $19.5 \pm 1.2$ & $24.6 \pm 1.2$ & $52.5 \pm 1.3$ & 0.49 & $55.8 \pm 1.2$ & 59.4 \\
\hline
\end{tabular}

${ }^{\mathrm{a}}$ in duplicate; ${ }^{\mathrm{b}_{\text {in }} \text { triplicate. }}$

WS: wheat straw; $D_{50}$ : median size; SA: Surface Area; Cell: Cellulose; Hem: Hemicelluloses; Crl: Crystallinity index.

$\mathrm{SA}=(\mathrm{Sp} / \mathrm{p}) / \mathrm{p}$

$\mathrm{Sp}=$ surface of particle $\left(\mathrm{m}^{2}\right)=4 \pi\left((\mathrm{Zp} / 2)^{2}\right) ; \mathrm{Zp}$ : Particle size $(\mathrm{m})$.

$\mathrm{Vp}=$ volume of particle $\left(\mathrm{m}^{3}\right)=4 / 3 \pi((\mathrm{Zp} / 2) 3)$.

$\rho$ : density of particle $\left(\mathrm{g} / \mathrm{m}^{3}\right)$.

charged fractions $\mathrm{F}+$ were bluer than the negatively charged fractions F- (more brownish), whereas the starting material F0 is a mixture of two fractions. Figure 2 shows that the morphology of the positively charged fractions differed from negatively charged fractions and unfractionated WS (F0). The positively charged fractions contain homogeneous and non-fibrous small particles. Conversely, the negatively charged fractions contain more heterogeneous and fibrous long particles. Hemery et al. [11] obtained similar results with wheat bran after successive ES. This difference in color and morphology could be due to the difference in composition, depending on the origin of the tissues. The separation process also influenced the particle median diameter $\mathrm{D}_{50}$. Indeed it was observed that at each separation step, the positively charged $\mathrm{F}+$ fractions were composed of finer particles than the corresponding negatively charged $\mathrm{F}-$ fractions (Table 1 ). Except the fractions adhering to the electrodes, F1A-E $(42.2 \mu \mathrm{m})$ fraction is finer compared to $\mathrm{F} 1 \mathrm{~B}+\mathrm{E}$ fraction with $\mathrm{D}_{50}$ of $44.9 \mu \mathrm{m}$. ES leads to a particle size of $52.2 \mu \mathrm{m}$ and $62.6 \mu \mathrm{m}$ for $\mathrm{F} 1 \mathrm{~B}+$ and $\mathrm{F} 2 \mathrm{~B}+$, respectively compared to $81.2 \mu \mathrm{m}, 95.7 \mu \mathrm{m}$ and $81.9 \mu \mathrm{m}$ for F1A-, F2A- and F0, respectively (Table 1 ). The surface area (SA) varied also according to charge of particles (Table 1). Generally, the positively charged fractions exhibited a larger surface compared to negatively charged particles except F1A-E. It can be seen in Table 1 that ES leads to a SA of 42.5, 37.3 and $47.1 \mathrm{~m}^{2} / \mathrm{g}$ for $\mathrm{F} 1 \mathrm{~A}-, \mathrm{F} 2 \mathrm{~A}-$ and $\mathrm{F} 2 \mathrm{~B}-$, respectively compared to $43.6 \mathrm{~m}^{2} / \mathrm{g}$ for F0 and $60.2,63.2$ and $59.4 \mathrm{~m}^{2} / \mathrm{g}$ for $\mathrm{F} 1 \mathrm{~B}+, \mathrm{F} 2 \mathrm{~B}+$ and $\mathrm{F} 2 \mathrm{~A}+$, respectively.

Miao et al. [20] investigated the mechanical size reduction of miscanthus and switchgrass using a commercial hammer mill and the resulting SA was measured using the geometry and density of particles. This method yielded accessible SA of 20.4 and $20.5 \mathrm{~m}^{2} / \mathrm{g}$ when a hammer mill was used to grind miscanthus and switchgrass, respectively, with a screen size of $1 \mathrm{~mm}$ [20]. They reported that, in general, the SA increases linearly with particle size. Literature data reported that a decrease in particle size and an increase of reactive SA could facilitate the process of enzymatic hydrolysis $[10,21]$. ES also influenced cellulose crystallinity. It was observed that the negatively charged fractions $\mathrm{F}$ - exhibited higher $\mathrm{CrI}$ compared to F0 and positive fractions $\mathrm{F}+$. It can be seen in Table 1 that ES leads to a CrI of 58.8, 63.5 and $60.4 \%$ for $\mathrm{F} 1 \mathrm{~A}-, \mathrm{F} 1 \mathrm{~A}-\mathrm{E}$ and $\mathrm{F} 2 \mathrm{~A}-$, respectively compared to $51.9,51.3$ and $52.3 \%$ for $\mathrm{F} 1 \mathrm{~B}+, \mathrm{F} 1 \mathrm{~B}+\mathrm{E}$ and $\mathrm{F} 2 \mathrm{~B}+$. It is widely accepted that crystalline cellulose is less accessible to cellulase attack than amorphous cellulose [22-25].

Ultrafine milling combined with ES technology resulted in the separation of the high crystalline cellulose F- and low crystalline cellulose F+ of WS without adding chemical catalysts and solvent extraction. The successive refineries also influenced the biochemical composition of the positively $\mathrm{F}+$ and negatively $\mathrm{F}$ - charged fractions, as shown in Table 1 and Figure 3. It can be observed that the positively charged fractions $\mathrm{F}+$ were richer in cellulose compared to F0 and negatively charged F- fractions. Whereas, negatively charged $\mathrm{F}$ - fractions were rich in lignin, hemicelluloses (and thus arabinoxylans) and ash compared to positively charged $\mathrm{F}+$ fractions. This corresponds to hem:cell ratios of $0.77,0.82,0.68$ and 0.81 for $\mathrm{F} 1 \mathrm{~A}-$, F2A-, F2B- and F1A-E compared to 0.45, 0.37, 0.49 and 0.37 for $\mathrm{F} 1 \mathrm{~B}+, \mathrm{F} 2 \mathrm{~B}+, \mathrm{F} 2 \mathrm{~A}+$ and $\mathrm{F} 1 \mathrm{~B}+\mathrm{E}$, respectively and to 0.66 for F0 (Table 1 ).

ES is a very effective technology to isolate or separate fractions enriched in various biopolymers or byproducts without solvent utilization and effluent production. For 

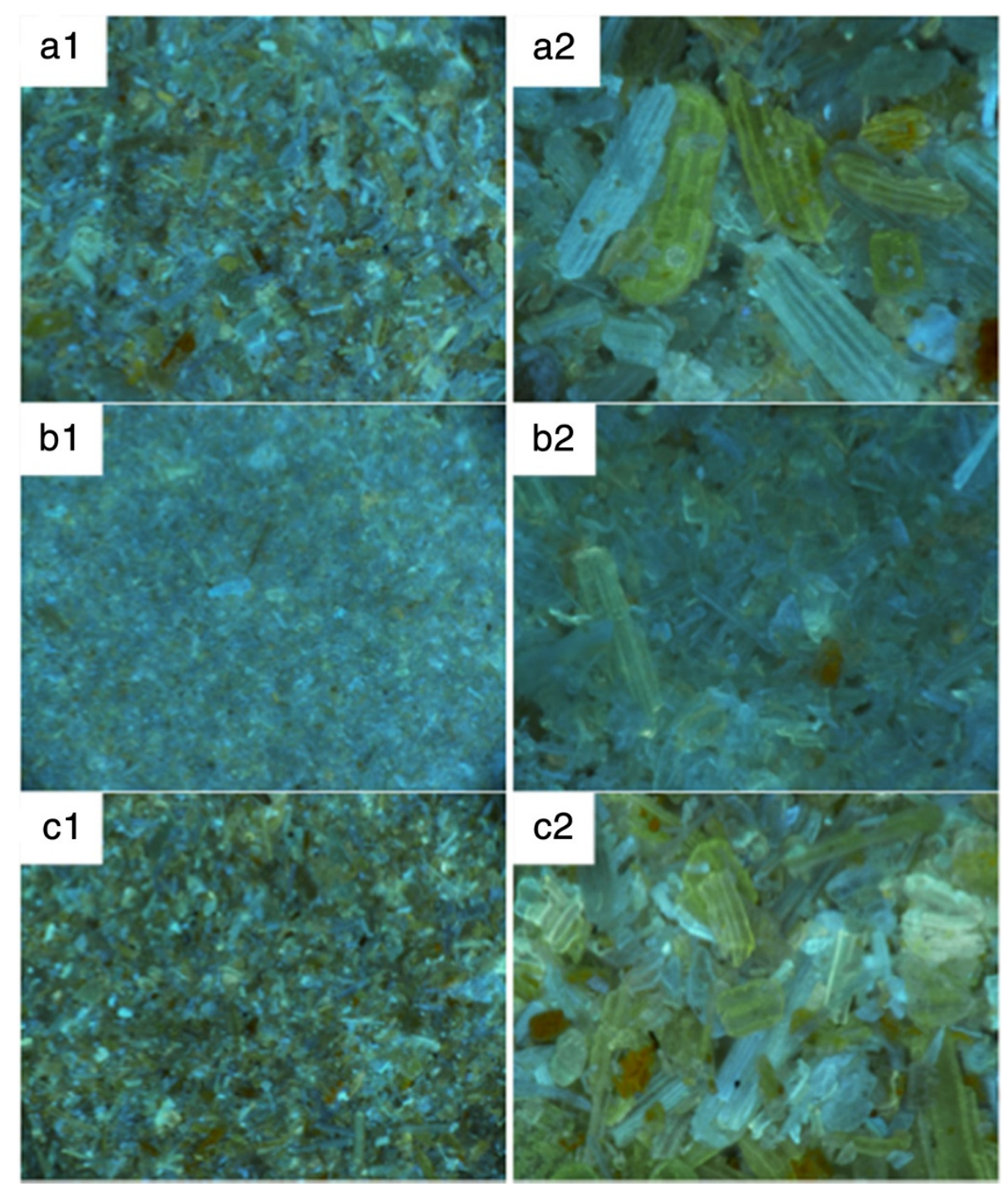

Figure 2 Micrographic and morphology of unfractionated WS: a1) $\times 5$ and a2) $\times 25$, Positively charged fractions: b1) $\times 5$ and $\mathbf{b 2}$ ) $\times 25$, and negatively charged fractions $\mathbf{c 1}$ ) $\times 5$ and $\mathbf{c 2}$ ) $\times 25$. WS: Wheat straw.

instance, in the case of F2B+ fraction, an increase of 33\% for cellulose and decrease of $30 \%$ for hemicelluloses were observed compared to the starting material F0 (Table 1). Also, it can be seen in Table 1 that F1A-E fraction (the material that was found stuck to the electrodes) exhibited a very singular composition, characterized by $30.3,16.7$ and $37.6 \%$ of hemicelluloses, lignin and cellulose, respectively. Moreover, it exhibited a very high degree of cellulose crystallinity (63.5\%), high reactive surface $\left(70.7 \mathrm{~m}^{2} / \mathrm{g}\right)$ and high ash content (15.3\%) compared to the unfractionated WS F0 and to other fractions (Table 1). Figure 3 also shows that the negatively charged fractions $\mathrm{F}$ - are richer in ferulic acid (FA), which is known to be a characteristic of the complex lignin-xylan in the gramineous lignocellulosic plants. In contrast, the positively charged fractions $\mathrm{F}+$ are richer in $p$-coumaric acid ( $p$-CA) and ferulic acid dimer (diFA).

Table 1 and Figure 3 show that at each fractionation or refinery step (Figure 1c) the positively charged particles contained more cellulose and phenolic acids ( $p$-CA and $\operatorname{diFA}$ ) than the negatively charged particles and the starting material F0. This corresponded to the observed increase in cellulose content in the positively charged fractions; $55.2 \%$ after the first fractionation step and $58.4 \%$ after the second fractionation step. The successive refineries steps also resulted in an increase in the content of hemicellulose and FA in the negatively charged fractions and in a decrease of cellulose content phenolic acids ( $p$-CA and diFA). The difference in color, microstructure, biochemical composition and structure could depend on the origin of the tissues, which clearly indicates 


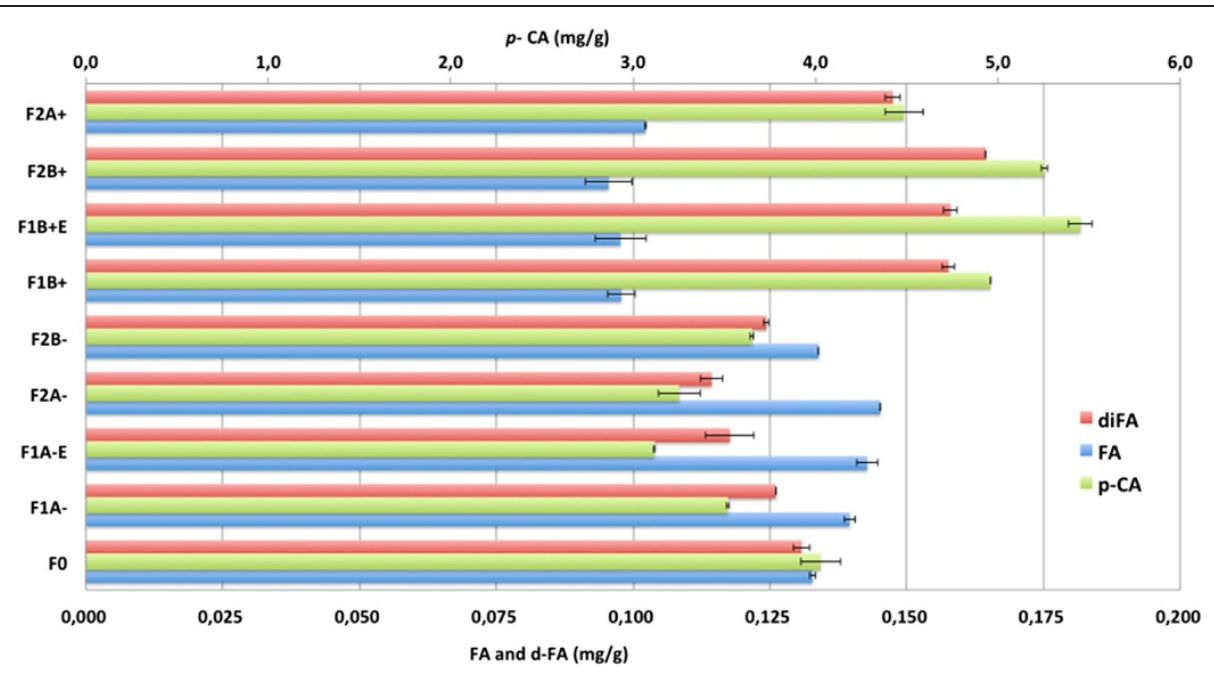

Figure 3 Yield ( $\mathrm{mg} \mathrm{g}^{-1}$ ) of $p$-coumaric acid, ferulic acid and di-ferulic acid in different WS fractions. diFA: di-ferulic acids (ferulic acids dimer); FA: Ferulic acid; $p$-CA, p-coumaric acid.

that using ES, would make it possible to separate different lignocellulosic tissues and fractions, displaying very different structures and biochemical compositions.

\section{Enzymatic hydrolysis of wheat straw fractions and energy efficiency}

After each separation step, WS fractions were hydrolyzed with a commercial enzymatic cocktail at biomass loadings of $10 \%$ in buffer and enzymatic loadings of 20 FPU (filter paper unit) $\mathrm{g}^{-1}$ for 72 hours [10]. The effects of each separation step (Figure 1 and Figure 4) were evaluated by determining the glucose and xylose released ( $\mathrm{mg} \mathrm{g}^{-1}$ fraction). The data presented in Figure 4 illustrate that the maximum glucose yield after 72 hours was obtained with positively charged fractions $\mathrm{F}+$, with a yield of about 258, 254 and $203 \mathrm{mg}$ glucose $\mathrm{g}^{-1}$ of $\mathrm{F} 1 \mathrm{~B}+\mathrm{E}, \mathrm{F} 2 \mathrm{~B}+$ and $\mathrm{F} 1 \mathrm{~B}+$ fractions, respectively. There was a highly significant difference observed in the glucose and xylose yield obtained for positively charged fractions $\mathrm{F}+$ compared to negatively charged fractions $\mathrm{F}-$ and starting material F0. The glucose yields after 72 hours of hydrolysis was 130, 121, 135 and $103 \mathrm{mg} \mathrm{g}^{-1}$ of F0, F1A-, F1A-E and F2A- respectively. Whereas, the maximum xylose yield was obtained with negatively charged fractions $\mathrm{F}-$, with a yield of about 83,90 and $83 \mathrm{mg}$ xylose $\mathrm{g}^{-1}$ of F1A-, F1A-E and F2A- respectively, compared to $88 \mathrm{mg}^{\text {xylose }} \mathrm{g}^{-1}$ of F0 and 52, 54 and $42 \mathrm{mg}$ xylose $\mathrm{g}^{-1}$ of $\mathrm{F} 1 \mathrm{~B}+, \mathrm{F} 1 \mathrm{~B}+\mathrm{E}$ and $\mathrm{F} 2 \mathrm{~B}+$ respectively. These results suggest that the positively charged fractions $\mathrm{F}+$ are more accessible to cellulase than the negatively charged fractions $\mathrm{F}-$.

ES technology has allowed for very effective isolating and separating of poor enzymatically accessible or recalcitrant tissues $\mathrm{F}$ - from the more accessible tissues or fractions $\mathrm{F}+$. In comparison to another mechanical treatment developed in literature (Table 2), Maache-Rezzoug et al. [26] compared the effect of mechanical treatment on glucan conversion, and found that glucose yield increased with a decrease in particle size [26]. They obtained 120 and $150 \mathrm{mg} \mathrm{g}^{-1}$ WS of glucose with particle sizes of $600-1000 \mu \mathrm{m}$ and 50-600 $\mu \mathrm{m}$, respectively. Silva et al. [27] also investigated the effect of mechanical treatment on enzymatic hydrolysis of WS and obtained about $108 \mathrm{mg} \mathrm{g}^{-1}$ WS of reducing sugars with a mean

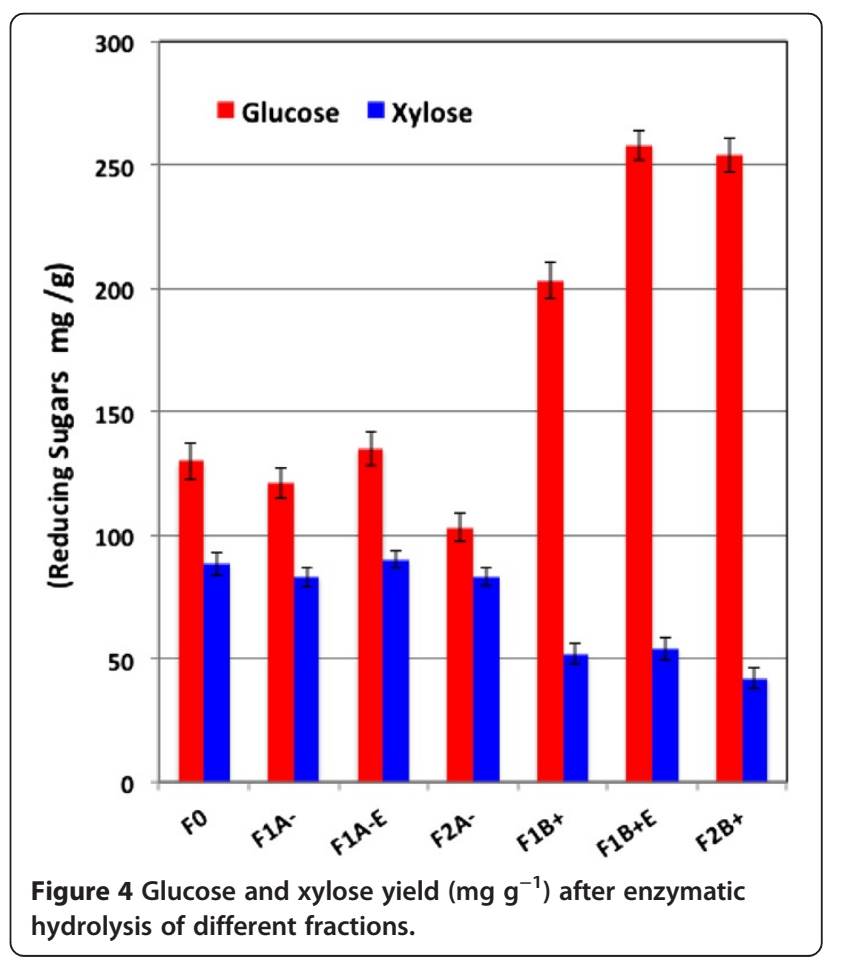


Table 2 Comparison of various WS pretreatments with dry fractionation technology developed in this work

\begin{tabular}{|c|c|c|c|c|c|c|}
\hline Pretreatment conditions & $\begin{array}{l}\text { Enzymatic hydrolysis } \\
\text { conditions }\end{array}$ & Glucose (mg/g WS) & $\begin{array}{l}\text { Reducing } \\
\text { sugars } \\
\text { (mg/g WS) }\end{array}$ & $\begin{array}{l}\text { Solvent } \\
\text { or water } \\
\text { (L/Kg WS) } \\
\end{array}$ & $\begin{array}{l}\text { Chemical } \\
\text { reagent } \\
\text { (Kg/Kg WS) }\end{array}$ & Reference \\
\hline \multicolumn{7}{|l|}{ Mechanical } \\
\hline $50-600 \mu m$ & \multirow{2}{*}{$\begin{array}{l}\text { Celluclast- } 1.5 \mathrm{~L} \text { Trichoderma } \\
\text { reesei, } 50^{\circ} \mathrm{C}, 20 \text { hours }\end{array}$} & 150 & ND & 0 & 0 & \multirow[t]{2}{*}[27]{} \\
\hline $600-1000 \mu m$ & & 120 & ND & 0 & 0 & \\
\hline Ball milling 240 hour, $10 \mu \mathrm{m}$ & \multirow{2}{*}{$\begin{array}{l}\text { Cellulase Trichoderma } \\
\text { reesei, } 37^{\circ} \mathrm{C} \text {, } 48 \text { hours }\end{array}$} & N.D. & 270 & 0 & 0 & \multirow[t]{2}{*}[28]{} \\
\hline Centrifugal milling: $270 \mu \mathrm{m}$ & & N.D. & 108 & 0 & 0 & \\
\hline Milling + electrostatic fractionation: $50-70 \mu \mathrm{m}$ & $\begin{array}{l}\text { Cellulase Trichoderma } \\
\text { Longibrachiatum } 37^{\circ} \mathrm{C} \text {, } \\
72 \text { hours }\end{array}$ & $254^{*}$ & $294^{*}$ & 0 & 0 & This study \\
\hline \multicolumn{7}{|l|}{ Chemical } \\
\hline $750 \mu \mathrm{m}$, glycerol $70 \%, 230^{\circ} \mathrm{C}, 4$ hours & \multirow{4}{*}{$\begin{array}{l}\text { Celluclast- } 1.5 \mathrm{~L} \text { Trichoderma } \\
\text { reesei, } 50^{\circ} \mathrm{C}, 2.5 \mathrm{~h}\end{array}$} & 268 & 423 & 20 & 0 & \multirow[t]{3}{*}[30]{} \\
\hline $\begin{array}{l}750 \mu \mathrm{m} \text {, ionic liquid/WS ratio: } 25 / 1 \mathrm{w} / \mathrm{w}, \\
150^{\circ} \mathrm{C}, 1 \text { hour }\end{array}$ & & 368 & 744 & 0.03 & 25 & \\
\hline $750 \mu \mathrm{m}, 1 \%$ acid, $140^{\circ} \mathrm{C}, 40$ minutes & & 176 & 223 & 20 & 1 & \\
\hline \multicolumn{6}{|l|}{ Physicochemical } & \\
\hline $\begin{array}{l}833 \mu \mathrm{m} \text {, water } / \text { S ratio: } 40 / 1, \text { Steam } \\
\text { explosion: } 210^{\circ} \mathrm{C}, 10 \text { minutes }\end{array}$ & $\begin{array}{l}\text { Cellulase } \mathrm{BTXL} \text { Trichoderma } \\
\text { reesei, } 50^{\circ} \mathrm{C}, 72 \text { hours }\end{array}$ & ND & 117 & 40 & 0 & \multirow[t]{3}{*}{ [31] } \\
\hline $\begin{array}{l}833 \mu \mathrm{m}, 50 \% \mathrm{v} / \mathrm{v} \text { acetic acid, steam explosion: } \\
220^{\circ} \mathrm{C}, 8 \text { minutes }\end{array}$ & & ND & 244 & 40 & 20 & \\
\hline $\begin{array}{l}833 \mu \mathrm{m}, 70 \% \mathrm{v} / \mathrm{v} \text { ethanol steam explosion: } \\
220^{\circ} \mathrm{C}, 5 \text { minutes }\end{array}$ & & ND & 264 & 40 & - & \\
\hline $\begin{array}{l}833 \mu \text { m, supercritical } \mathrm{CO}_{2} 190^{\circ} \mathrm{C}, 12 \mathrm{MPa} \text {, } \\
30 \text { minutes }\end{array}$ & $\begin{array}{l}\text { Cellulase Trichoderma } \\
\text { reesei, } 50^{\circ} \mathrm{C}, 72 \text { hours }\end{array}$ & ND & 149 & ND & ND & \multirow[t]{2}{*}{ [32] } \\
\hline $\begin{array}{l}833 \mu \mathrm{m} \text {, steam explosion (A) } 200^{\circ} \mathrm{C} \\
15 \text { minutes + supercritical } \mathrm{CO}_{2}: 190^{\circ} \mathrm{C}, 12 \mathrm{MPa} \text {, } \\
30 \text { minutes }\end{array}$ & & ND & 234 & ND & ND & \\
\hline
\end{tabular}

ND not determined; WS: wheat straw.

${ }^{*} 254 \mathrm{~g} \mathrm{Kg}^{-1}$ of glucose and $294 \mathrm{gKg}^{-1}$ of reducing sugars obtained for $\mathrm{F} 2 \mathrm{~B}+$ fraction after ES.

particle size of $270 \mu \mathrm{m}$, which was obtained with centrifugal milling, and the maximum reducing sugars yield was $240 \mathrm{mg} \mathrm{g}^{-1}$ WS obtained with a particles size of $10 \mu \mathrm{m}$, produced by ball milling for 240 hours (Table 2). This indicates that the accessibility does not depend only on the particle size and/or the cellulose crystallinity, but also on parameters such as the reactive SA, lignin and ash contents, and lignin-xylan association [7,25,28,29].

In this study, we confirm this hypothesis - that negatively charged fractions F- or tissues characterized by a heterogeneous and coarse particle content, richer in lignin-xylan and ash, and with more crystalline cellulose, are less accessible and produce lower glucose yields compared to initial FO and to positively charged fractions $\mathrm{F}+$, characterized by high reactive SA and fine particle size, a lower lignin content and less crystalline cellulose (Table 1). The combination strategy of simultaneous ultrafine milling and ES improve the economic feasibility by low energy consumption $\left(10.5 \mathrm{WhKg}^{-1}\right)$ compared, for example, to ball milling and steam or hot water, which consumes high energy. ES technology also produced different tissues and fractions with different physicochemical structures and properties in a short time, which can be easily converted to biofuels and byproducts without using chemicals and/or water and without generating toxic effluent.

\section{Comparison of electrostatic separation technology} efficiency with the others wheat straw pretreatments The energy efficiency $\eta$ (g glucose extracted $\mathrm{Wh}^{-1}$ ) was used to compare the performance of lignocellulose pretreatments $[2,18]$. The amount of glucose recovered after enzymatic hydrolysis ( $g$ glucose $\mathrm{Kg}^{-1}$ biomass) was divided by the total energy consumed for fractionation or pretreatment processes ( $\mathrm{WhKg}^{-1}$ biomass). However, literature concerning the energy consumption and energy efficiency of chemical, physicochemical and mechanical treatment is scarce. The total energy consumption $\left(\mathrm{E}_{\text {tot }}\right)$ of the fractionation technology developed in this current work has been calculated from Equation 1:

$$
\mathrm{E}_{\mathrm{tot}}=\mathrm{E}_{\mathrm{M}}+\mathrm{E}_{\mathrm{ES}}
$$


Where EM is the specific energy consumption required during the milling of WS using screen size of $0.1 \mathrm{~mm}$, and $\mathrm{E}_{\mathrm{ES}}$ is the specific energy consumption during the ES fractionation of WS (fraction F0).

The specific energy requirement $\left(\mathrm{E}_{\mathrm{M}}\right)$ to milling raw material using an impact knife mill (Figure 1a) with $0.1 \mathrm{~mm}$ screen sizes for producing F0 fraction was 125.7 $\mathrm{WhKg}^{-1}$. In contrast, only $10.5 \mathrm{WhKg}^{-1}$ was required for positively charged $\mathrm{F}+$ and negatively charged $\mathrm{F}-$ fractions production from F0 fraction (Figure $1 \mathrm{~b}$ and $\mathrm{c}$ ). This clearly indicates that ES technology consumes less energy compared to milling equipment used to reduce particle size, such as knife and ball milling, and to thermal pretreatments, such as steam and hot water [7,33,34]. As a consequence, the combination of ultrafine milling and ES for the production of positively and negatively charged fractions consumed approximately $136.2 \mathrm{WhKg}^{-1}\left(\mathrm{E}_{\mathrm{tot}}\right)$. The total energy requirement $\left(\mathrm{E}_{\mathrm{tot}}\right)$ was used to calculate the energy efficiency $(\eta)$. The highest $\eta$ was the more effective pretreatment or of biomass. The maximum glucose yield extracted was $258 \mathrm{~g} \mathrm{Kg}^{-1}$ of $\mathrm{F} 1 \mathrm{~B}+\mathrm{E}$ and $254 \mathrm{~g} \mathrm{Kg}^{-1}$ of F2B+ and after ES and hydrolysis, whereas only $130 \mathrm{~g}$ $\mathrm{Kg}^{-1}$ of F0 was obtained of unfractionated WS. The highest $\eta$ obtained was $1.86 \mathrm{~g}$ glucose $\mathrm{Wh}^{-1}$ for $\mathrm{F} 2 \mathrm{~B}+\mathrm{E}$ and $\mathrm{F} 2 \mathrm{~B}+$ compared to $1.03 \mathrm{~g}$ glucose $\mathrm{Wh}^{-1}$ for unfractionated WS (F0), representing a gain of $0.70 \mathrm{~g}$ glucose $\mathrm{Wh}^{-1}$. In comparison, Silva et al. [27] reported that the maximum reducing sugars yield, obtained with BM at 240 hours, was $240 \mathrm{mg} \mathrm{g}^{-1} \mathrm{WS}$, consuming more energy than the combination of milling and ES technology developed in this study $[7,33]$.

In comparison, the energy efficiency of acid and alkaline pretreatment of oilseed rape (OSR) straw was evaluated [35]. The maximum sugar extracted after acid pretreatment and hydrolysis was obtained from biomass pretreated for 90 minutes. However the $\eta$ was found to be higher when biomass has been pretreated for $60 \mathrm{mi}$ nutes; hence, the highest $\eta$ obtained was 0.94 g glucose $\mathrm{Wh}^{-1}$ from a pretreatment time of 60 minutes. However, during alkaline pretreatment, the highest glucose yield (462 g glucose $\mathrm{Kg}^{-1}$ biomass) was obtained by pretreating biomass for 30 minutes at $0.63 \mathrm{~mol} / \mathrm{dm}^{3} \mathrm{NaOH}$ concentration [35]. The highest $\eta$ obtained after alkaline pretreatment was $1.42 \mathrm{~g}$ glucose $\mathrm{Wh}^{-1}$ by pretreating biomass for 30 minutes at $130^{\circ} \mathrm{C}$ and a $\mathrm{NaOH}$ concentration of 0.63 and $0.75 \mathrm{~mol} / \mathrm{dm}^{3}$. The authors have shown that a higher glucose concentration can be extracted from OSR straw per watt-hour of energy consumed, when alkaline pretreatment was used in contrast to acid pretreatment.

da Silva et al. [36] studied the efficiency of wet disk milling (WDM) on bagasse and sugarcane straw for bioethanol production. They reported that the maximum sugar yields were obtained after 20 cycles WDM for both bagasse and straw, which yielded 213 and $245 \mathrm{~g}$ glucose $\mathrm{Kg}^{-1}$ biomass, respectively. However, the highest $\eta$ obtained was 0.046 and $0.027 \mathrm{~g}$ glucose $\mathrm{Wh}^{-1}$, for bagasse and straw biomass, respectively after only 10 cycles of WDM, while 20 cycles consumed the highest amount of energy, corresponding to the lowest $\eta$. Hideno et al. [37] also compared the efficiency energy of BM, WDM and hot compressed water treatment HCWT. They suggested that the optimal milling time was 60 minutes with the highest yield of glucose (331 mg glucose $\mathrm{g}^{-1}$ RS). However, BM treatment at 60 minutes resulted in lower $\eta$ compared to WDM at 5 minutes and 10 minutes for the pretreatment of RS. The highest $\eta$ obtained was $0.078 \mathrm{~g}$ glucose $\mathrm{Wh}^{-1}$, for $\mathrm{RS}$ after $\mathrm{BM}$ at 5 minutes. The HCWT of RS were performed at $160^{\circ} \mathrm{C}$ and $180^{\circ} \mathrm{C}$. The glucose yield after enzymatic hydrolysis at $180^{\circ} \mathrm{C}$ was $313 \mathrm{mg}$ glucose $\mathrm{g}^{-1} \mathrm{RS}$, higher than that at $160^{\circ} \mathrm{C}$ and higher than WDM treatment for one cycle. But in terms of energy efficiency, a WDM pretreatment of one cycle is more preferable than $\mathrm{HCWT}$ at $180^{\circ} \mathrm{C}$ [37]. These results clearly indicate that energy efficiency is an important parameter that can be used in the comparison of the efficiency of different lignocellulosic pretreatments.

In Table 2, we reported a different WS pretreatment; however, it is very difficult to carry out an in-depth comparison because most published studies were conducted under a wide variety of conditions. As a consequence, the comparison of the combination of dry milling and ES technology developed in this study with ionic liquid or dilute acid and steam explosion pretreatments was not evident (Table 2). A global harmonization initiative is needed. It can be seen in the Table 2 that the electrostatic fractionation technology of WS developed in this work required low energy $\left(10.5 \mathrm{Wh} \mathrm{Kg}^{-1}\right)$ and produced a high glucose yield (254 $\mathrm{mg} \mathrm{g}^{-1}$ ) without using chemicals and without wastewaters. This can be compared to $150 \mathrm{mg} \mathrm{g}^{-1}$ obtained with a mechanical treatment [26], $268 \mathrm{mg} \mathrm{g}^{-1}$ WS obtained with a particle size of $750 \mu \mathrm{m}$ using $70 \%$ glycerol at $230^{\circ} \mathrm{C}$ for 4 hours [38], $368 \mathrm{mg} \mathrm{g}^{-1}$ using ionic liquid with a liquid/WS ratio of $25 / 1 \mathrm{w} / \mathrm{w}$ (25 Kg ionic liquid $\mathrm{Kg}^{-1} \mathrm{WS}$ ) at $150^{\circ} \mathrm{C}$ for 1 hour [38], $176 \mathrm{mg} \mathrm{g}^{-1}$ with a particle size of $750 \mu \mathrm{m}$ using $1 \%$ of sulfuric acid at $140^{\circ} \mathrm{C}$ for 40 minutes [38], and $264 \mathrm{mg} \mathrm{g}^{-1}$ of total sugars obtained with a particle size of $833 \mu \mathrm{m}$ after steam explosion using ethanol $70 \% \mathrm{v} / \mathrm{v}$ at $220^{\circ} \mathrm{C}$ for $5 \mathrm{mi}$ nutes [30]. Some of these different studies developed on WS used a high quantity of water, chemical reagent and solvent and generated high levels of effluent and produced fermentation inhibitors, which have a severe environmental impact (Table 2). The simultaneous combination of milling and electrostatic fractionation of lignocellulose biomass could improve the economic feasibility by low energy consumption and produce reactive lignocellulose particles with different physicochemical structures in a short 
time, which can be converted easily to biofuels without using chemicals or water and without generating toxic effluent.

We conclude from this discussion that in order to compare or to evaluate the efficiency and the performance of different lignocellulose pretreatments and fractionation methods some parameters are necessary, such as: the energy requirement to reduce the particle size; the energy consumption during thermochemical treatments and drying process; glucose or reducing sugars yield; the energy consumed during separation, extraction, and solvent recycling; and the quantity of chemical reagent, water and solvent used in the pretreatment.

\section{Conclusions}

The combination of milling and ES of WS as a continuous dry fractionation process produced interesting fractions which exhibit a very different structure and composition. Homogeneous and crumbly fractions rich in cellulose were clearly more abundant in the positively charged particle fractions, and heterogeneous and fibrous fractions rich in lignin-hemicelluloses and ash were more abundant in the negatively charged fractions. The positively charged fractions are more accessible to enzymes, permitting a high glucose yield, which could be used as substrate for biofuels. However, the negatively charged fractions are more recalcitrant and contained more lignin-xylan and ash, which are less accessible to enzymes. The combination of milling and ES technology appears to be an interesting new fractionation continuous process for the development of environmental lignocellulosic biorefinery for biofuels and byproducts or biomaterials production, without using chemical and without wastewaters generation.

\section{Materials and methods}

\section{Fractionation of wheat straw}

WS was obtained from a local farm (Languedoc-Roussillon region, France). WS was coarsely cut to less than $2 \mathrm{~mm}$ by knife milling SM 100 (Retsch, Germany). WS sample (2 $\mathrm{mm}$ particle size) was also ground using an impact knife mill (Hosokawa-alpine, type UPZ, Augsburg, Germany, Figure 1a), operated at ambient temperature at a speed of $18000 \mathrm{rpm}$, with a $0.1 \mathrm{~mm}$ screen size (Figure 1a and $\mathrm{b}$ ). After milling, the unfractionated WS powder (F0) was introduced directly into a Tribo-electrostatic Separator Pilot (TEP System, Lexington, United States; Figure 1a) is shown in Figure 1a and b. The particles were conveyed by compressed air at $1 \mathrm{Kg} \mathrm{h}^{-1}$ in a charging line where they were tribo-charged, by impacting each other and impacting against the walls of the charging line (Figure 1a and b). The charged particles were then injected into a separation chamber containing two high voltage electrodes $(10000 \mathrm{~V})$, where the positively charged particles are attracted by the negative electrode and the negatively charged particles are attracted by the positive electrode (Figure 1b). A particle recovery system equipped with two cyclones allowed for the separate recovery of the two fractions (one containing the positively charged particles and the other, the negatively charged particles). These two separated fractions underwent a second separation step, giving four different fractions (Figure 1c).

When the starting material was F0 only two separation steps were carried out: the fractions F1A- and F1B+ were obtained from F0 as a result of the first separation step, while the fractions $\mathrm{F} 2 \mathrm{~A}$ - were obtained from $\mathrm{F} 1 \mathrm{~A}-$, and the fractions $\mathrm{F} 2 \mathrm{~B}+$ were obtained from $\mathrm{F} 1 \mathrm{~B}+$ as a result of the second fractionation step (Figure 1c).

The total energy $\left(E_{\text {tot }}\right)$ consumed during the fractionation process, defined as the sum of $E_{M}$ and $E_{E S}$, was calculated. The total energy consumption $\left(E_{\text {tot }}\right.$ in $\left.\mathrm{WhKg}^{-1}\right)$ was measured according to Equation $1 . \mathrm{E}_{\mathrm{M}}$ and $\mathrm{E}_{\mathrm{ES}}$ are measured using a wattmeter PX110 (Power meter, Meteix, France). The power active, active electric energy (Wh), frequency hertz and time were logged into a PC card at 1 -second intervals [10].

\section{Characterization of wheat straw fractions}

WS sample (F0, F1A-, F2A-, F2B-, F1A-E, F1B+, F2B+, $\mathrm{F} 2 \mathrm{~A}+$ and $\mathrm{F} 1 \mathrm{~B}+\mathrm{E}$ ) were analyzed for their particle size, color, biochemical composition, crystallinity and microstructure and enzymatic accessibility. The particle size was analyzed by laser granulometry Mastersizer 2000 (Malvern Instrument, Orasy, France) and the particle density was determined using ultra Pycnometer 1000 (Quantachrome Instrument, United States). The carbohydrate and lignin composition of lignocellulosic samples was measured after concentrated acid hydrolysis according to the method described by Barakat et al. [10]. Phenolic acids were also analyzed using the method described by Antoine et al. [31]. Ester-linked phenolic acids were saponified under argon (oxygen-free) at $35^{\circ} \mathrm{C}$ in $2 \mathrm{~N}$ sodium hydroxide (Sigma Chemical Co., St Louis, United States) An internal standard (2,3,5 trimethoxy-(E)cinnamic acid, T-4002, Sigma Chemical Co., St Louis, United States) was added before adjusting the $\mathrm{pH}$ to 2 . Phenolic acids 371 were then extracted with diethylether and quantified by high-performance liquid chromatography. The response factors of $p$-CA, vanillic acid (VA), FA and diFA were determined at $320 \mathrm{~nm}$ with purified samples, relative to the internal standard. The FA monomer content was calculated from the amount of cis- and trans-ferulic acid.

The crystallinity of different WS fractions was determined by X-ray diffraction. Powder X377 ray diffraction patterns were recorded on a Bruker diffractometer D8 Advance (Bruker corporation, Germany). The measurements were conducted on powder-compacted on small 
mats. X-Ray-diffraction data were collected from $2 \theta=5$ to $50^{\circ}$ with a step interval of $0.02^{\circ}$. The degree of crystallinity can be expressed as the percentage crystallinity index [10].

\section{Enzymatic hydrolysis}

Enzymatic hydrolysis of treated and untreated WS was performed using a commercial enzymatic cocktail (Trichoderma longibrachiatum C9748) (20 FPU g ${ }^{-1}$ ) obtained from Sigma Aldrich (Sigma Chemical Co., St Louis, United States). Enzymatic hydrolysis was conducted at a solid concentration of $10 \%(\mathrm{w} / \mathrm{v})$ in $50 \mathrm{mM}$ sodium acetate buffer $\left(\mathrm{pH} \mathrm{5.0)}\right.$ at $37^{\circ} \mathrm{C}$ for 72 hours with agitation. Sodium azide (Sigma Chemical Co., St Louis, United States) was added at the end of the experiment to inhibit microbial growth. The experiment was performed in triplicate. The enzymatic digestibility was evaluated from the obtained soluble sugars $\left(\mathrm{mg} \mathrm{g}^{-1}\right)$ determined by high phase liquid chromatography analysis [10].

\section{Abbreviations}

П: Energy efficiency; BM: Ball milling; Crl: Crystallinity index; E: Energy; ES: Electrostatic separation; $E_{M}$ : Energy consumption required during milling; EES: energy consumption during ES; FA: Ferulic acid; $\mathrm{p}$-CA: p-coumaric acid; SA: Surface area; WDM: Wet disc milling; WS: Wheat straw; VA: Vanillic acid.

\section{Competing interests}

The authors declare that they have no competing interests.

\section{Authors' contributions}

$A B$ designed and carried out the experiments, analyzed results and wrote the manuscript. XR assisted and reviewed the manuscript. Both authors read and approved the final manuscript.

\section{Acknowledgments}

The authors are grateful to Dr Cécile BARRON for his help in microscopy analysis.

Received: 3 April 2014 Accepted: 4 September 2014

Published online: 24 September 2014

\section{References}

1. Watanabe T, Shino A, Akashi K, Kikuchi J: Spectroscopic investigation of tissue-specific biomass profiling for Jatropha curcas L. Plant Biotechnol 2012, 29:163-170

2. Anderson WF, Akin DE: Structural and chemical properties of grass lignocelluloses related to conversion for biofuels. J Ind Microbiol Biotechnol 2008, 35:355-366.

3. Wilson: Organization of forage plant tissues. In Forage cell wall structure and digestibility. Edited by Jung HG, Buxton DR, Hatfield RD, Ralph R. Segoe Rd., madison, WI 53711 USA: ASA-CSSA-SSSA; 677 S; 1993:1-32.

4. Kamm B, Kamm M: Principles of biorefineries. Appl Microbiol Biotechnol 2004, 64:137-145.

5. Galbe M, Zacchi G: Pretreatment: the key to efficient utilization of lignocellulosic materials. Biomass Bioenergy 2012, 46:70-78.

6. George W, Huber SI, Avelino C: Synthesis of transportation fuels 421 from biomass: chemistry, catalysis, and engineering. Chem Rev 2006, 106:4044-4098.

7. Barakat A, de Vries H, Rouau X: Dry fractionation process as an important step in current and future lignocellulose biorefineries: a review. Bioresour Technol 2013, 134:362-373.

8. Daniel J, Schell $\mathrm{CH}$ : Milling of lignocellulosic biomass. Appl Biochem Biotechnol 1994, 45-46:159-168.

9. Jin $\mathrm{S}$, Chen $\mathrm{H}$ : Fractionation of fibrous fraction from steam-exploded rice straw. Process Biochem 2007, 42:188-192.
10. Barakat A, Chuetor S, Monlau F, Solhy A, Rouau X: Eco-friendly dry chemo-mechanical pretreatments of lignocellulosic biomass: Impact on energy and yield of the enzymatic hydrolysis. Appl Energy 2014, 113:97-105.

11. Hemery $Y$, Holopainen U, Lampi A-M, Lehtinen P, Nurmi T, Piironen V, Edelmann M, Rouau X: Potential of dry fractionation of wheat bran for the development of food ingredients, part II: Electrostatic separation of particles. J Cereal Sci 2011, 53:9-18.

12. Papatheofanous MG, Billa E, Koullas DP, Monties B, Koukios EG: Optimizing multisteps mechanical 441 chemical fractionation of wheat straw components. Indu Corp Products 1998, 7:249-256.

13. Abecassis $J$, de Vries $H$, Rouau $X$ : New perspective for biorefining cereals. Biofuels Bioprod Biorefin 2013, 8:462-474.

14. Chundawat SP, Venkatesh B, Dale BE: Effect of particle size based separation of milled corn stover on AFEX pretreatment and enzymatic digestibility. Biotechnol Bioeng 2007, 96:219-231.

15. Zhu JY, Wang GS, Pan XJ, Gleisner R: Specific surface to evaluate the efficiencies of milling and pretreatment of wood for enzymatic saccharification. Chem Eng Sci 2009, 64:474-485.

16. Jin $\mathrm{S}$, Chen $\mathrm{H}$ : Superfine grinding of steam-exploded rice straw and its enzymatic hydrolysis. Biochem Eng J 2006, 30:225-230.

17. Hemery Y, Rouau X, Dragan C, Bilici M, Beleca R, Dascalescu L: Electrostatic properties of wheat bran and its constitutive layers: influence of particle size, composition, and moisture content. J Food Eng 2009, 93:114-124.

18. Kachi M, Dascalescu L: Corona discharges in asymmetric electrode configurations. J Electrostatics 2014, 72:6-12.

19. Samuila A, Blajan M, Beleca R, Huzau M, Morar R, Dascalescu L, Luga A: Modeling of wire corona electrode operation in electrostatic separation at small and large gaps. J Electrostatics 2005, 63:955-960.

20. Miao Z, Grift TE, Hansen AC, Ting KC: Energy requirement for comminution of biomass in relation to particle physical properties. Indu Corps and Product 2011, 33(2):504-513.

21. Bernardo C, Vidal BSD Jr, Ting KC, Vijay S: Influence of feedstock particle size on lignocellulose conversion - a review. Appl Biochem Biotechnol 2011, 164:1405-1412.

22. Caulfield DF, Moore WE: Effect of varying crystallinity of cellulose on enzyme hydrolysis. Wood Sci 1974, 6:375-379.

23. Guo GL, Hsu DC, Chen WH, Chen WH, Hwang WS: Characterization of enzymatic saccharification for acid-pretreated lignocellulosic materials with different lignin composition. Enzyme Microb Technol 2009, 45:80-87.

24. Inoue H, Yano S, Endo T, Sakaki T, Sawayama S: Combining hot-compressed water and ball milling pretreatments to improve the efficiency of the enzymatic hydrolysis of eucalyptus. Biotechnol Biofuels 2008, 1:1-9.

25. Zhu L, O'Dwyer JP, Chang VS, Granda CB, Holtzapple MT: Structural features affecting biomass enzymatic digestibility. Bioresour Technol 2008, 99:3817-3828

26. Maache-Rezzoug Z, Pierre G, Nouviaire A, Maugard T, Rezzoug SA: Optimizing thermomechanical pretreatment conditions to enhance enzymatic hydrolysis of wheat straw by response surface methodology. Biomass Bioenergy 2011, 35:3129-3138.

27. Silva GGD, Couturier M, Berrin JG, Buleon A, Rouau X: Effects of grinding processes on enzymatic degradation of wheat straw. Bioresour Technol 2012, 103:192-200

28. Monlau FBA, Trably E, Dumas C, Steyer JP, Carrere H: Lignocellulosic materials into biohydrogen and biomethane: impact of structural features and pretreatment. Critical Rev In Environ Sci Technol 2013, 43:260-322.

29. Mosier N, Wyman C, Dale B, Elander R, Lee YY, Holtzapple M, Ladisch M: Features of promising technologies for pretreatment of lignocellulosic biomass. Bioresour Technol 2005, 96:673-686.

30. Zabihi S, Alinia R, Esmaeilzadeh F, Kalajahi JF: Pretreatment of wheat straw using steam, steam/acetic acid and steam/ethanol and its enzymatic hydrolysis for sugar production. Biosystems Eng 2010, 105:288-297.

31. Antoine C, Peyron S, Lullien-Pellerin V, Abecassis J, Rouau X: Wheat bran tissue fractionation using biochemical markers. J Cereal Sci 2004, 39:387-393.

32. Alinia R, Zabihi S, Esmaeilzadeh F, Kalajahi JF: Pretreatment of wheat straw by supercritical $\mathrm{CO}_{2}$ and its enzymatic hydrolysis for sugar production. Biosystems Eng 2010, 107:61-66.

33. Kratky $L$, Jirout T: Biomass size reduction machines for enhancing biogas production. Chem Eng Technol 2011, 34:391-399. 
34. Zhu JY, Pan XJ: Woody biomass pretreatment for cellulosic ethanol production: Technology and energy consumption evaluation. Bioresour Technol 2010, 101:4992-5002.

35. Mathew AK, Chaney K, Crook M, Humphries AC: Alkaline pre-treatment of oilseed rape straw for bioethanol production: Evaluation of glucose yield and pre-treatment energy consumption. Bioresour Technol 2011, 102:6547-6553.

36. da Silva ASA, Inoue H, Endo T, Yano S, Bon EPS: Milling pretreatment of sugarcane bagasse and straw for enzymatic hydrolysis and ethanol fermentation. Bioresour Technol 2010, 101:7402-7409.

37. Hideno A, Inoue H, Tsukahara K, Fujimoto S, Minowa T, Inoue S, Endo T, Sawayama S: Wet disk milling pretreatment without sulfuric acid for enzymatic hydrolysis of rice straw. Bioresour Technol 2009, 100:2706-2711.

38. Guragain YN, De Coninck J, Husson F, Durand A, Rakshit SK: Comparison of some new pretreatment methods for second generation bioethanol production from wheat straw and water hyacinth. Bioresource Technol 2011, 102:4416-4424.

doi:10.1186/s13068-014-0138-2

Cite this article as: Barakat and Rouau: New dry technology of environmentally friendly biomass refinery: glucose yield and energy efficiency. Biotechnology for Biofuels 2014 7:138.

\section{Submit your next manuscript to BioMed Central and take full advantage of:}

- Convenient online submission

- Thorough peer review

- No space constraints or color figure charges

- Immediate publication on acceptance

- Inclusion in PubMed, CAS, Scopus and Google Scholar

- Research which is freely available for redistribution 